\title{
GERAKAN KEWIRAUSAHAAN SOSIAL BERBASIS BUDIDAYA ANGGREK (Studi dan Rekonstruksi Konsep pada Budidaya Anggrek Padma Orchid Yogyakarta)
}

\author{
Irma Yuliani \\ Fakultas Ekonomi dan Bisnis Islam UIN Sunan Kalijaga Yogyakarta \\ Corresponding author: irmayuliani82@gmail.com
}

\begin{abstract}
This study aims to find the observations regarding community empowerment based on the orchid cultivation. In addition, this research attemps to construct the concept of community empowerment through a partnership pattern. The elements that have built the partnership include private sector, academics, government, and society. The existence of the private sector is believed to be able to encourage business development through adequate capital, the existence of the government is very important to ensure smooth empowerment and business traffic activities, and the existence of academics can support the development of empowerment and improvement in the quality of empowerment through research activities. Three main patterns are found in this partnership; first, the research development patterns; Second, marketing patterns and; Third, advocation patterns. These patterns are believed to be able to provide effective solutions and strategies so that orchid-based community empowerment activities can be carried out properly and sustainably.
\end{abstract}

Keywords: orchid cultivation, community empowerment, social entrepreneurship, concept reconstruction

\begin{abstract}
Abstrak: Penelitian ini bertujuan untuk memperoleh hasil pengamatan mengenai pemberdayaan masyarakat berbasis budidaya anggrek. Selain itu penelitian ini juga berupaya untuk melakukan rekonstruksi konsep pemberdayaan masyarakat melalui pola kemitraan. Adapun elemen-elemen yang mempelopori terwujudnya kemitraan ini diantaranya adalah pihak swasta, akademisi, pemerintah, dan masyarakat. Keberadaan pihak swasta diyakini mampu mendorong pengembangan usaha melalui permodalan yang memadai, keberadaan pemerintah sangat penting untuk menjamin lancarnya kegiatan pemberdayaan dan lalu lintas usaha, serta keberadaan akademisi dapat menunjang pengembangan pemberdayaan serta peningkatan kualitas pemberdayaan melalui kegiatan riset. Tiga pola utama yang ditemukan dalam kemitraan ini adalah pola pengembangan riset, pola pemasaran serta pola pendampingan. Ketiga pola tersebut diyakini dapat memberikan solusi dan strategi yang efektif sehingga kegiatan pemberdayaan masyarakat berbasis budidaya anggrek dapat terlaksana dengan baik dan berkelanjutan.
\end{abstract}

Kata Kunci: budidaya anggrek, pemberdayaan masyarakat, gerakan kewirausahaan sosial, dan rekonstruksi konsep

\section{PENDAHULUAN}

Menurut Steenis (1972) anggrek merupakan tumbuhan berbunga yang sangat beragam dan tergolong ke dalam familia Orchidaceae. Keindahan bentuk bunga serta distribusi yang luas menyebabkan anggrek menjadi tanaman yang popular. Di Indonesia terdapat kurang lebih 5.000 spesies anggrek dari 20.000 hingga 30.000 spesies yang tersebar di seluruh dunia. Dari 5.000 jenis anggrek yang ada di Indonesia, 1.327 jenis di antaranya tumbuh di Pulau Jawa dan selebihnya tumbuh di Pulau Sumatera, 
Kalimantan, Sulawesi, Irian Jaya, dan pulau lainnya (Rombang, 1999).

Tanaman anggrek umumnya lebih banyak dimanfaatkan sebagai tanaman hias. Tanaman anggrek juga dianggap sebagai tanaman yang mahal dan membutuhkan pemeliharaan yang lebih ekstra. Dalam beberapa kasus yang terjadi, budidaya anggrek lebih banyak digemari oleh masyarakat kalangan menengah keatas dan belum banyak tersentuh oleh lapisan masyarakat menengah ke bawah.

Asumsi yang demikian ini mengakibatkan minimnya terobosan-terobosan yang dapat diaktualisasikan untuk menciptakan nilai ekonomis pada tanaman anggrek di seluruh lapisan masyarakat. Disamping itu juga belum banyak ditemukan aksi-aksi nyata seperti pemberdayaan masyarakat melalui budidaya tanaman anggrek. Padahal, jika dicermati lebih jauh, tanaman anggrek sebetulnya bisa dipelihara oleh siapapun, tidak terkecuali masyarakat kalangan menengah ke bawah. Tentu untuk mewujudkan pemberdayaan ini diperlukan upaya yang sinergis antara beberapa pihak.

Padma Orchid merupakan salah satu usaha budidaya anggrek di wilayah Yogyakarta yang baru saja berdiri pada bulan Februari 2018. Pendirian Padma Orchid pada mulanya bertujuan untuk mengembangkan industri anggrek dan ikut serta menjadi industri yang dapat mensuport pemenuhan produk ekspor dari hasil budidaya anggrek. Namun dalam perkembangannya, pihak swasta pemilik kebun anggrek ini memilih untuk melanjutkan prospek usahanya dalam bidang pemberdayaan masyarakat.

Pemberdayaan masyarakat tani didefinisikan sebagai proses perubahan pola pikir, perilaku dan sikap petani dari subsistem tradisional menjadi petani modern yang berwawasan agribisnis melalui proses pembelajaran yang berkelanjutan. Salah satu bentuk pemberdayaan yang diyakini dapat memberikan dampak yang signifikan terhadap peningkatan ekonomi masyarakat adalah gerakan sosial entrepreneur atau kewirausahaan sosial. Kewirausahaan sosial adalah pemanfaatan perilaku kewirausahaan yang lebih berorientasi untuk pencapaian tujuan sosial dan tidak mengutamakan perolehan laba, atau laba yang diperoleh dimanfaatkan untuk kepentingan sosial. Seorang profesor yang pakar di bidang kewirausahaan sosial, Gregory Dees (1998), menyatakan bahwa kewirausahaan sosial merupakan kombinasi dari semangat besar dalam misi sosial dengan disiplin, innovasi, dan keteguhan seperti yang lazim berlaku di dunia bisnis (Utomo, 2014). Sedangkan menurut Bill Drayton (1980) seorang pendiri Ashoka Foundation/Penggagas kewirausahaan sosial) yang dikutip dari Sofia (2015) terdapat dua kunci utama dalam kegiatan kewirausahaan sosial, 1) adanya inovasi sosial yang mampu mengubah sistem yang ada di masyarakat, 2) hadirnya individu bervisi, kreatif, berjiwa wirausaha (entrepreneurial), dan beretika di belakang gagasan inovatif tersebut (Sofia, 2015).

Dalam referensi selanjutnya disebutkan bahwa karakteristik wirausaha sosial selalu melibatkan diri dalam proses inovasi, adaptasi, pembelajaran yang terus menerus tanpa menghiraukan berbagai hambatan atau keterbatasan yang dihadapinya dan memiliki akuntabilitas dalam mempertanggungjawabkan hasil yang dicapainya kepada masyarakat. Definisi komprehensif di atas memberikan pemahaman bahwa social entrepreneurship terdiri dari empat elemen utama yakni social value, civil society, innovation, and economic activity (Palesangi, 2012).

Penelitian yang sama oleh Palesangi, menemukan bahwa kewirausahaan sosial merupakan salah satu alternatif untuk mengatasi masalah sosial berupa pengangguran, kemiskinan, dan kerusakan lingkungan (Palesangi, 2012). Berdasarkan data yang direlease oleh litbang pertanian, produk agribisnis yang memiliki prospek paling tinggi masih didominasi oleh produk perkebunan, yaitu karet. Sedangkan untuk produk holtikultura, khususnya anggrek, diperkirakan membutuhkan investasi yang tinggi untuk mengembangkan industri tersebut. Sasaran pengembangan industri anggrek hingga saat ini masih diutamakan untuk peningkatan ekspor. Hal tersebut mengakibatkan nilai investasi yang dibutuhkan cukup besar. Berdasarkan data historis oleh litbang pertanian, investasi pemerintah dan swasta untuk pengembangan industri anggrek masing-masing sebesar Rp. 150 Milyar dan Rp. 397.233 Milyar dalam kurun waktu 5 tahun (2005-2010). Dalam pengembangan industri anggrek dibutuhkan 
investasi pemerintah dan swasta. Investasi pemerintah dibutuhkan untuk mengembangkan infrastruktur, pembinaan, penelitian dan pengembangan. Sedangkan investasi swasta cenderung untuk pengembangan anggrek itu sendiri (Badan Litbang Pertanian, 2018).

Melihat nilai investasi yang tinggi untuk mewujudkan usaha anggrek, maka diperlukan berbagai macam strategi agar pemberdayaan masyarakat dapat terwujud. Kemitraan merupakan salah satu strategi yang dapat diterapkan dalam mengembangakan kewirausahaan sosial dalam bidang budidaya anggek. Keberadaan pihak swasta dapat menopang pengembangan usaha melalui permodalan yang memadai, keberadaan pemerintah juga sangat penting untuk menjamin lancarnya kegiatan pemberdayaan dan lalu lintas usaha, serta keberadaan akademisi dapat menunjang pengembangan pemberdayaan serta peningkatan kualitas pemberdayaan melalui kegiatan risetnya.

Beberapa hasil penelitian mengenai peningkatan produktivitas produk holtikultura memberikan rekomendasi dalam rangka meningkatkan daya saing produk holtikultura, diantaranya yaitu: a) menerapkan strategi peningkatan produktivitas dan peningkatan kualitas produk; b) menggalakkan kerjasama dengan BUMN dalam optimalisasi lahan; c) mengajak pihak swasta untuk menginvestasikan dananya; d) melakukan pendekatan terhadap lembaga pertanian dalam rangka meningkatkan produktivitas produk (Hidayat, 2017).

Pranadji (2006) dalam penelitiannya menemukan bahwa pemberdayaan masyarakat pedesaan akan lebih efektif jika dilandaskan pada penguatan modal sosial. Adapun komponen dari penguatan modal sosial tersebut diantaranya meliputi tata nilai, kompetisi SDM, manajemen sosial, keorganisasian masyarakat, struktur sosial, kepemimpinan, dan penyelenggaraan pemerintah yang baik. Sinergitas antar komponen akan terwujud jika terjalin kemitraan. Beberapa penelitian menemukan bahwa konsep Triple helix dapat menjadi solusi guna terciptanya kolaborasi mutualisme antara pihak perguruan tinggi, pemerintah dan pelaku usaha (Izzati, 2018; Murniati, 2009; Praswati, 2017). Pemberdayaan masyarakat tani melalui budidaya anggrek termasuk jenis pemberdayaan yang belum banyak dilakukan. Dalam beberapa literatur dan penelitian juga disebutkan bahwa untuk mencapai ketahanan pangan secara berkelanjutan, indonesia perlu menciptakan pemberdayaan pelaku bisnis yang disinergikan dengan pihak akademisi dan pihak pemerintah ( Rahman, 2017).

Kemitraan merupakan modal yang penting untuk memecahkan berbagai permasalahan mengenai permberdayaan masyarakat. Kemitraan dapat mengubah pola pemberdayaan tani yang awalnya bersifat tradisional menjadi bersifat komersil dan berwawasan agroekonomi (Hunaepi et al., 2018; Purnaningsih, 2007).

Penelitian yang telah dilakukan oleh Yulianjaya dan Hidayat (2016) menemukan bahwa pola kemitraan yang terjalin antara juragan luar desa dengan petani mitra cenderung mengikuti pola kerjasama operasional agribisinis (KOA). Kedua pendapatan antar mitra meningkat ketika musim tanam 2015/2016, bahkan pendapatan petani mitra mencapai Rp. 35.100.558/Ha dan pendapatan juragan luar desa mencapai $\mathrm{Rp}$. 4.912.428/Ha (Yulianjaya dan Hidayat, 2016).

Selanjutnya dalam penelitian Rochdiani dan Suranta (2007) mengenai pola kemitraan antara petani padi dengan PT. E-Farm Bisnis Indonesia ditemukan hasil yang berbeda. Kemitraan yang terjali antar kedua belah pihak kurang optimal, dimana keterlibatan petani hanya sampai pada musim panen, sehingga pola kemitraan belum sampai dilaksanakan sebagaimana mestinya. Hal tersebut disebabkan oleh ketidakfahaman petani mengenai konsep yang dikembangkan perusahaan mitra dan kurangnya kapasitas penyimpanan dan pengolahan yang dimiliki oleh perusahaan (Rochdiani dan Suranta, 2007).

Penelitian mengenai pemberdayaan masyarakat melalui budidaya anggrek masih jarang dilakukan, hal ini disebabkan karena pola pemberdayaan melalui budidaya anggrek sendiri sangat jarang ditemui. Rekonstruksi konsep pembentukan kemitraan akan dideskripsikan untuk memberikan gambaran mengenai pola kemitraan yang efektif dan berkelanjutan. Berdasarkan latar belakang dan pertimbangan dari beberapa penelitian sebelumnya, penelitian ini bertujuan untuk mengungkap pola kemitraan antara akademisi, swasta, dan pemerintah sebagai basis 
pemberdayaan masyarakat melalui budidaya anggrek

\section{METODE PENELITIAN}

Penelitian ini merupakan penelitian kualitatif dengan paradigma induktif, yaitu melalui kegiatan pengamatan lapangan secara langsung dan kemudian dilanjutkan dengan pengembangan konsep. Data diperoleh dari pengamatan lapangan, wawancara, dan studi dokumen yang tersedia pada organisasi yang diamati. Populasi dalam penelitian ini adalah seluruh unit yang berperan dalam kegiatan kemitraan kewirausahaan sosial, baik pihak swasta, pemerintah, maupun akademisi. Adapun sampel penelitian hanya terbatas pada responden dengan frekuensi keterlibatan secara penuh dalam kegiatan yang dilakukan oleh pusat budidaya anggrek Padma Orchid, yaitu sejumlah 10 responden, yang terdiri dari 1 pemilik, 4 pengelola, 5 akademisi yang terlibat. Penelitian ini juga berupaya untuk merekonstruksi suatu konsep yang bertujuan untuk mengembangkan pola kemitraan antara pihak-pihak yang tergabung dalam kelompok gerakan kewirausahaan sosial.

Lokasi penelitian ini dilakukan di Pusat Budidaya Anggrek Padma Orchid Yogyakarta. Peneliti memilih obyek ini karena kemudahan obyek untuk diakses. Pengamatan ini dilakukan selama kurang lebih 4 bulan terhitung sejak bulan Mei 2018 hingga Agustus 2018. Adapun fokus pengamatan yang dilakukan diantaranya yaitu:

a. Melakukan pengamatan mengenai latar belakang terbentuknya pola kemitraan dalam bentuk gerakan kewirausahaan sosial yang berorientasi pada pengembangan kewirausahaan sosial dan pendampingan masyarakat;

b. Hubungan akademisi, pemerintah dan pihak swasta serta peran masing-masing unit dalam membangun gerakan kewirausahaan sosial;

c. Manfaat dari adanya masing-masing unit dan implementasinya dalam pelaksanaan kegiatan kewirausahaan sosial; serta

d. Melakukan rekonstruksi konsep melalui pola kemitraan antar unit.

\section{HASIL DAN PEMBAHASAN}

\section{Konsep Ide}

Kemitraan bukanlah konsep yang asing dalam kegiatan kewirausahaan. Bahkan kemitraan sudah menjadi sunnatullah dalam kehidupan. Manusia sebagai makhluk sosial tidak akan bisa menjalani kehidupan tanpa melibatkan individu lain dalam hidupnya. Maka bisa dipastikan dalam setiap aspek kehidupan, konsep kemitraan sejatinya telah terjadi dan menjadi kesatuan sistem. Namun dalam kasus penelitian ini, kemitraan yang dibangun terdiri dari berbagai komponen dengan tujuan mengoptimalkan kapasitas dan fungsi dari setiap elemen yang tergabung. Melalui kemitraan tersebut diaharapkan dapat melahirkan gerakan kewirausahaan sosial yang bertumpu pada optimalisasi peran swasta, akademik, maupun pemerintah dalam melakukan advokasi kepada masyarakat.

Ide kemitraan yang terwujud antara pusat budidaya anggrek Padma Orchid, akademik, pemerintah, maupun swasta tentu bukan hal yang baru, akan tetapi munculnya ide tersebut diilhami dari berbagai fenomena sosial ekonomi yang sudah banyak terjadi di kalangan masyarakat umum. Hal yang berbeda pada konsep ide ini terletak pada bentuk implementasi kemitraan, tujuan kemitraan dalam jangka waktu panjang dan berkelanjutan.

Pembahasan mengenai ide kemitraan pada paper ini akan dimulai dari latar belakang terbentuknya kemitraan pada gerakan kewirausahaan sosial Padma Orchid. Berikut awal mula model terbentuknya kemitraan pada gerakan kewirausahaan sosial Padma Orchid:

\section{Latar Belakang Terbentuknya Kemitraan}

Padma Orchid merupakan pusat budidaya anggrek yang didirikan pada tahun 2018 dan memiliki salah satu tujuan ikut serta dalam meningkatkan kegiatan sosial, dalam hal ini adalah memberdayakan ekonomi masyarakat melalui budidaya anggrek.

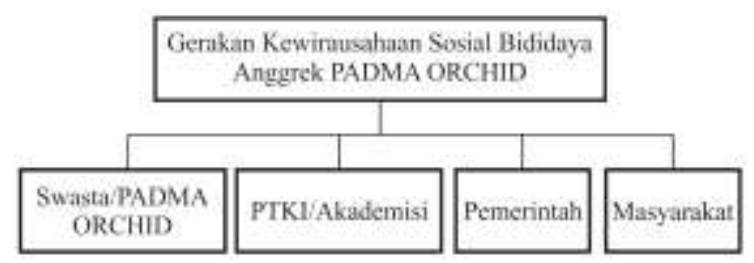

Gambar 1. Struktur Kemitraan 
Padma Orchid juga membuka peluang bagi mahasiswa atau praktisi anggrek untuk melakukan riset maupun pengembangan studi mengenai anggrek. Selain itu Padma Orchid juga membuka peluang untuk kegiatan magang, baik untuk mahasiswa ataupun masyarakat umum.

Kegiatan bisnis yang dilakukan oleh Padma Orchid adalah menjual pelatihan budidaya anggrek kepada masyarakat umum serta menerima jual beli hasil budidaya dan menyediakan berbagai peralatan, tanaman siap berbunga serta media untuk kegiatan budidaya. Networking yang dibangun oleh Padma Orchid secara luas diharapkan dapat menjadi pasar dan rekan kerjasama baik dalam kegiatan pemasaran produk maupun pemasaran pelatihan. Padma Orchid juga sudah mempersiapkan agar nantinya hasil budidaya anggrek ini bisa mencapai pasar luar negeri atau dapat mengekspor hasil budidayanya.

Selain untuk mencapai tujuan komersil, seperti yang telah disampaikan sebelumnya bahwa Padma Orchid memiliki cita-cita besar, yaitu ikut serta dalam memberdayakan masyarakat luas melalui budidaya anggrek. Disinilah awal mula lahirnya sebuah gerakan social entrepreneur berbasis budidaya anggrek. Gerakan ini pertama kali dirintis pada tanggal 29 Mei 2018. Melalui kegiatan workshop yang diselenggarakan oleh Padepokan Musa Asy'ari, pada tanggal 29 Mei 2018 hasil workshop menyepakati untuk didirikan sebuah gerakan yang bertujuan untuk memandirikan ekonomi ummat, maka lahirlah gerakan kewirausahaan sosial Padepokan Musa Asy'ari.

Gerakan Kewirausahaan Sosial Padepokan Musa Asy'ari ini kemudian merintis berbagai program diantaranya adalah budidaya anggrek dengan menggandeng berbagai elemen penting seperti pihak akademik, pemerintah, serta masyarakat setempat untuk dijadikan obyek yang diberdayakan dalam kelangsungan program ini.

Adapun penggagas dan pihak yang memiliki keterlibatan dalam kegiatan kewirausahaan sosial Padma Orchid yaitu:

1. Swasta

Berdirinya kewirausahaan sosial Padma Orchid tidak terlepas dari keberadaan pihak swasta, dalam hal ini adalah pemilik Padma Orchid. Dalam beberapa literature dan penelitian sebelumnya juga didapatkan bahwa keberadaan pihak swasta sangat berarti dalam kegiatan penanaman modal dan pemicu kelangsugan kegiatan bisnis. Untuk itu dibutuhkan kepedulian yang tinggi dari pihak swasta agar kewirausahaan sosial dapat berlangsung dengan baik dan memberikan dampak yang signifikan terhadap ekonomi masyarakat sekitar.

2. Akademik

Inisiasi lahirnya gerakan kewirausahaan sosial ini tidak bisa terlepas dari konstribusi Perguruan Tinggi dalam hal ini adalah kaum akademisi. Workshop sosial entrepreneur yang diselenggarakan pada tangal 29 Mei 2018 tersebut dihadiri oleh berbagai kaum akademisi terutama dari Universitas Muhammadiyah Surakarta, Universitas Islam Negeri Sunan Kalijaga, IAIN Salatiga, Sekolah Tinggi Ilmu Ekonomi SBI, dan para praktisi wirausaha dari berbagai daerah serta para pengurus pondok pesantren. Pada saat itu hasil workshop menyepakati adanya beberapa wakil daerah untuk menjadi inisiator pelaksanaan gerakan kewirausahaan. Sehingga melalui networking yang dibangun pada masing-masing daerah, gerakan kewirausahaan ini bisa melahirkan silaturrahim hingga ditingkat nasional. Kaum akademisi memiliki peran penting kaitannya dengan hal ini. Perumusan gerakan kewirausahaan tidak bisa terlepas dari konstribusi pemikiran dan sumbangan konsep dari para akademisi. Selanjutnya peran yang akan dijalankan oleh kaum akademisi dalam kemitraan ini akan disampaikan lebih detail pada point pola kemitraan. Konstribusi yang semacam ini seharusnya bisa diadopsi oleh Perguruan Tinggi di Indonesia, yang mana kaum akademisi sebagai manifestasi dari Perguruan Tinggi bisa menjadi agent of innovation and development dalam kegiatan advokasi masyarakat.

3. Pemerintah

Lembaga pemerintah yang bekerja dengan efektif dan efisien akan berdampak positif bagi pelaku bisnis. Peraturan sebagai manifestasi dari fungsi pelayanan kepada masyarakat diharapkan dapat memberikan pengayoman dan dapat melindungi 
warganya. Ketika pemerintah daerah mau berinteraksi langsung dengan masyarakat dan dunia usaha tentu mereka akan mampu berkonstribusi langsung dan ikut serta mengembangkan dunia usaha. Pemerintah dapat memberikan pelayanan berupa perijinan usaha kepada masyarakat, mendata usaha, bahkan membantu dengan memberikan suntikan dana dan bantuan teknisnya lainnya.

\section{Masyarakat}

Memberdayakan masyarakat berarti memandirikan masyarakat dalam segi ekonomi maupun yang lainnya. Masyarakat yang mandiri adalah masyarakat yang mampu membuka peluang kerja untuk dirinya sendiri, dalam hal ini masyarakat diberdayakan melalui kegiatan wirausaha. Selain menjadi obyek yang diberdayakan, melalui budidaya anggrek ini masyarakat juga berperan sebagai rumah tangga yang nantinya akan membeli maupun memasok hasil budidaya. Dalam kegiatan ini maka akan tercipta demand dan supply antara masyarakat dan pasar budidaya anggek. Penjelasan lebih detail akan dijelaskan melalui point mekanisme kemitraan yang terbangun.

\section{Struktur Kemitraan}

Pola pada Gambar 2 memberikan gambaran mengenai interaksi antar pihak-pihak yang terlibat dalam menggagas kewirausahaan sosial Padma Orchid.

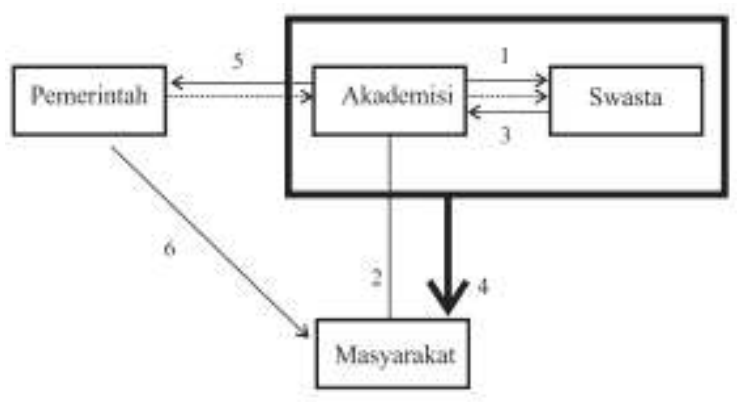

Gambar 2. Struktur Kemitraan

Mekanisme interaksi kemitraan di atas juga menjadi landasan terbentuknya gerakan kewirausahaan sosial berbasis budidaya anggrek. Namun karena dilapangan peran dan fungsi antar elemen belum terlaksana secara optimal, maka disini perlu adanya rekonstruksi konsep untuk memberikan alternatif dan inovasi dalam meningkatkan kembali kinerja masing-masing elemen. Adapun interaksi yang terbangun dalam pembentukan kemitraan ini adalah sebagai berikut:

1. Akademisi membangun hubungan dengan pembudidaya anggrek, awalnya hubungan ini hanya sekedar pemanfaatan green house sebagai laboratorium pembelajaran maupun pengembangan riset mengenai anggrek. Pada tahap selanjutnya akademisi mulai mengajukan ide untuk mengembangkan pusat budidaya anggrek menjadi bagian dari kegiatan sosial yang nantinya melibatkan masyarakat untuk diberikan pelatihan;

2. Bersamaan dengan pengajuan ide kepada pihak swasta, selanjutnya akademisi mengonfirmasi masyarakat untuk ikut serta bergabung dalam pelatihan budidaya anggrek. Akademisi memperkenalkan anggrek kepada masyarakat dan menjelaskan nilai komersil yang bisa dijadikan peluang berwirausaha. Setelah melihat respon yang cukup baik dari masyarakat, selanjutnya akademisi melaporkan informasi ini kepada pihak swasta;

3. Pengajuan ide dan rencana kegiatan disetujui dan diterima oleh pihak swasta. Maka kegiatan pengenalan dan pelatihan budidaya anggrek mulai dilaksanakan. Selama periode pelaksanaan pelatihan, baik dari pihak swasta maupun akedemisi, keduanya ikut serta berperan aktif;

4. Secara bersama-sama akademisi dan pihak swasta ikut serta berperan memberikan pelatihan ini kepada masyarakat. Akademisi berkonstribusi dalam menyampaikan bahan pelatihan, baik dari sisi teori maupun dari sisi praktik. Selanjutnya pihak swasta juga berkonstribusi dengan menyediakan sarana prasana pelatihan;

5. Selanjutnya setelah melihat semangat dan keaktifan yang tinggi dari setiap peserta, akademisi dan swasta berinisiasi untuk melanjutkan kegiatan ini tidak hanya sebatas di pelatihan. Kedua belah pihak ini akhirnya berinisiasi untuk melakukan pendampingan lebih lanjut, namun karena keterbatasan modal (sebab greenhouse ini awal mulanya berorientasi pada kegiatan 
komersil, jika harus lanjut ke tahap pendampingan dan penyediaan bibit untuk kegiatan budidaya diprediksi masih belum memumpuni). Akhirnya dari pertimbangan di atas, kedua belah pihak sepakat untuk mengajukan pendanaan kepada pemerintah dengan memanfaatkan dana pemberdayaan. Namun karena kendala anggaran, pengajuan ini sampai sekarang belum memperoleh respon yang pasti dari dinas pertanian.

6. Dari konsep kerja diatas, diharapkan nantinya pemerintah maupun pihak swasta setempat dapat memberikan suntikan modal kepada gerakan kewirausahaan sosial serta ikut memberikan dukungan yang lainnya terhadap kegiatan ini.

\section{Peran dan Hubungan antar Elemen}

Gambar 3 menunjukkan peran dan hubungan yang tercipta dari masing-masing elemen.

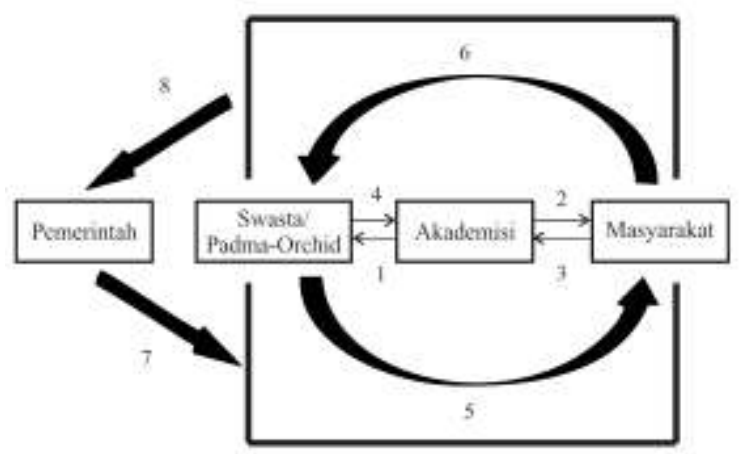

Gambar 3. Peran dan Hubungan antar elemen

Adapun peran dan hubungan tersebut adalah sebagai berikut:

1. Hubungan dan peran akademisi terhadap pihak swasta

a. Conceptor

Pihak akademisi yang diyakini memiliki kedalaman dari sisi teori dibanding elemen yang lain diharapkan mampu memberikan konsep kegiatan yang efektif, bermanfaat untuk seluruh pihak yang bergabung serta mampu mewujudkan kegiatan yang bersifat sustainable.

b. Innovator

Tidak jauh berbeda dengan seorang conceptor, keberadaannya sebagai innovator diharapkan juga mampu menuangkan ide cemerlangnya agar kegiatan pemberdayaan masyarakat berbasis budidaya anggrek terus berkembang dan inovatif.

2. Hubungan dan peran akademisi kepada masyarakat
a. Pekerja sosial dan pendamping masyarakat (Advocator);
b. Pelatih;
c. Educator;
d. Agent of innovation.

3. Hubungan dan peran masyarakat terhadap akademisi: Objek penelitian dan pengembangan masyarakat.

4. Hubungan dan peran swasta terhadap akademisi: Penyedia laboratorium pembelajaran dan pengembangan riset.

5. Hubungan dan peran swasta terhadap masyarakat
a. Penyedia sarana prasaran pelatihan;
b. Memberikan kesempatan kerja;
c. Pasar untuk menjual bibit dan peralatan budidaya anggrek.
d. Hubungan dan peran masyarakat terhadap swasta
e. Pemasok hasil budidaya/dalam bentuk tanaman seadling, atau sudah berbunga, serta tanaman siap dijual.

6. Hubungan dan peran pemerintah terhadap kesatuan antara swasta, akademisi, dan masyarakat
a. Regulator;
b. Penyedia dukungan modal usaha;
c. Penyedia dukungan teknis lainnya.

7. Hubungan dan peran kesatuan antara swasta, akademisi, dan masyarakat terhadap pemerintah
a. Ikut serta meningkatkan kegiatan wirausaha dalam rangka meningkatkan perekonomian nasional; serta
b. Menciptakan lapangan pekerjaan sehingga dapat mengurangi nilai pengangguran.

\section{Pola Kemitraan yang Terbangun}

1. Pengembangan riset

Pola kemitraan jenis pengembangan riset yang dikembangan melalui gerakan kewirausahaan sosial ini menghubungakan antara elemen masyarakat, swasta dan pihak akademisi. Akademisi sebagai subyek yang memiliki peran penting dalam hubungan ini membutuhkan masyarakat maupun swasta, dalam hal ini masyarakat diposisikan sebagai objek dan greenhouse 
budidaya anggrek sebagai instrumen sarana penelitain, terutama fasilitas laboratorium untuk kegiatan pengembangan penelitian.

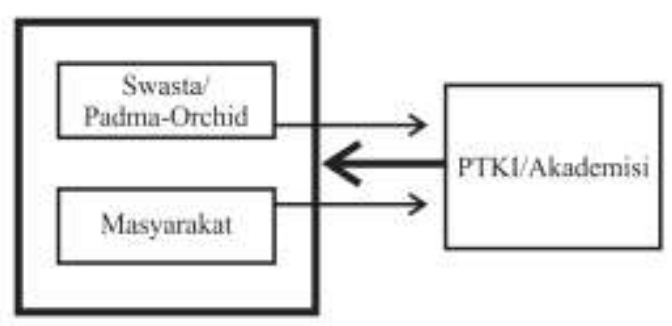

Gambar 4. Pola Pengembangan Riset

Adapun hasil dari penelitian yang dihasilkan oleh kaum akademisi selain untuk pengembangan studi akademik juga bermanfaat untuk kegiatan pengembangan hal-hal yang berhubungan dengan budidaya anggrek. Melalui kemitraan ini, masyarakat, swasta maupun akademisi menjadi hubungan mutualisme yang saling memberikan manfaat antara yang satu dengan yang lain.

2. Pemasaran

Salah satu tujuan paling fundamental dalam kemitraan ini adalah untuk memandirikan masyarakat dalam memenuhi kebutuhan ekonominya.

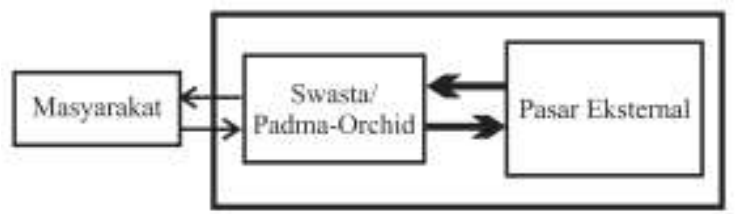

Gambar 5. Pola Pemasaran

Kemandirian itu akan terwujud jika masyarakat dapat menciptakan lapangan pekerjaan untuk dirinya sendiri. Salah satu unsur yang dapat mendukung tercapainya kegiatan wirausaha adalah unsur pemasaran. Saluran pemasaran yang tercipta antara elemen masyarakat, swasta, dan pasar eksternal akan memudahkan ketiganya menciptakan sebuah pasar. Melalui Gambar 5 dapat difahami, pertama: hubungan antara masyarakat dengan pihak swasta masing-masing akan saling berperan sebagai konsumen dan suplier. Pada awalnya pihak swasta akan berperan sebagai suplier bibit, media dan peralatan budidaya kepada pihak swasta, dalam kondisi ini masyarakat berperan sebagai konsumen. Selanjutnya setelah masyarakat menanam anggrek dan tiba untuk dijual, masyarakat akan menjual kembali anggrek hasil budidayanya kepada pihak swasta, pada situasi ini swasta berperan sebagai penerima penjualan, dan masyarakat berperan sebagai pemasok. Selanjutnya hasil budidaya yang telah diterima swasta dari pihak masyarakat akan diteruskan untuk dijual ke pasar eksternal, baik pasar dalam negeri maupun luar negeri.

3. Pendampingan

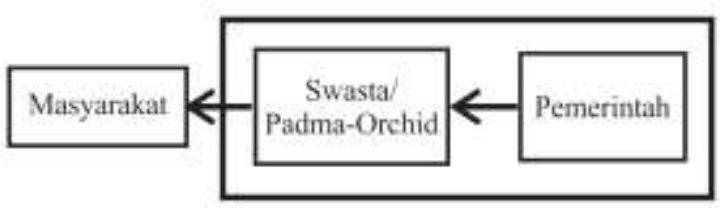

Gambar 6. Pola Pendampingan

Terwujudnya kedua pola kemitraan diatas tidak terlepas dari peran akademisi untuk mendampingi masyarakat sampai pada tahap mandiri. Di sini hubungan yang mungkin terjalin adalah hubungan antara akademisi, pemerintah dan masyarakat. Pemerintah juga memiliki peran penting dalam mendampingi masyarakat, baik secara langsung maupun tidak langsung. Misalnya dari pola diatas, pemerintah bisa memfasilitasi akademisi dengan memberikan pelatihan agar akademisi dapat meningkatkan skillnya dalam melakukan pengembangan budidaya anggrek. Setelah akademisi menerima transformasi ilmu dari pihak pemerintah, maka tahap selanjutnya adalah mentransformasikan pengetahuan dan skill yang ia peroleh kepada masyarakat.

\section{KESIMPULAN DAN SARAN}

\section{Kesimpulan}

1. Gerakan kewirausahaan sosial melalui budidaya anggrek merupakan salah satu alternatif wirausaha yang dapat digiatkan dalam rangka memberdayakan ekonomi masyarakat. Keberadaan pihak swasta dapat menopang pengembangan usaha melalui permodalan yang memadai, 
keberadaan pemerintah sangat penting untuk menjamin lancarnya kegiatan pemberdayaan dan lalu lintas usaha, serta keberadaan akademisi dapat menunjang pengembangan pemberdayaan serta peningkatan kualitas pemberdayaan melalui kegiatan risetnya.

2. Peran dan hubungan yang tercipta antara elemen akademik, swasta, pemerintah maupun masyarakat terwujud dalam berbagai hubungan timbal balik. Hubungan ini kemudian yang mempelopori terciptanya pola kemitraan. Adapun tiga pola kemitraan paling berpengaruh terhadap gerakan kewirausahaan sosial tersebut adalah pola pengembangan riset, pola pemasaran, dan pola pendampingan.

3. Pola pengembagan riset menempatkan kaum akademisi sebagai subyek utama pelaksana kegiatan. Namun dalam perjalanannya kaum akademisi tidak bisa mewujudkan kegiatan riset budidaya anggrek tanpa melibatkan kaum swasta sebagai penyedia sarana prasarana dan masyarakat sebagai obyek yang akan diobservasi perkembangannya. Selanjutnya pola pemasaran memberikan wadah kepada masyarakat untuk menyalurkan hasil budidaya anggrek agar dapat dijual sehingga ia akan memperoleh keuntungan.

4. Pola pendampingan menempatkan kaum akademisi dan kaum masyarakat sebagai pusat perhatian.

\section{Saran}

1. Hubungan antara akademisi dengan masyarakat harus terjalin lekat agar kaum akademisi mengetahui kekurangan yang harus ia sampaikan kepada masyarakat, atau jika menemukan suatu solusi juga dapat dibagikan kepada masyarakat, tujuannya agar kegiatan pemberdayaan ini dapat terlaksana dengan baik dan dapat mencapai cita-cita bersama.

2. Kegiatan pemberdayaan masyarakat berbasis holtikultura memang harus terus ditingkatkan, mengingat Indonesia adalah negara agraris, sehingga segala sumber daya alam berupa pertanian maupun perkebunan harus dimanfaatkan secara optimal.

3. Penelitian dan pengembangan konsep pemberdayaan melalui produk holtikultura berupa tanaman anggrek ini masih sangat terbatas, sehingga untuk penelitian yang akan datang, para peneliti bisa mengambil obyek penelitian yang lebih banyak dan bersifat heterogen, sehingga solusi-solusi dan strategi yang dipaparkan memungkinkan untuk diadopsi secara luas oleh berbagai lapisan masyarakat. Jika penelitian baru sebatas beberapa obyek tertentu seperti dalam penelitian ini, maka solusi dan strategi yang disajikan juga sebatas untuk obyek yang sedang diteliti, sehingga sulit untuk melakukan generalisasi hasil observasi.

\section{DAFTAR PUSTAKA}

Badan Litbang Pertanian. (2018/02/23). Prospek dan arah pengembangan agribisnis: Anggrek. Retrieved from http://www.litbang.pertanian.go.id/specia 1/komoditas/b3anggrek.

Hidayat, T. 2017. Kebijakan Pemerintah Indonesia Meningkatkan Ekspor Produk Holtikultura dalam Menghadapi Masyarakat Ekonomi Asean Tahun 2015. JOM FISIP, 4(1), 1-16.

Hunaepi, Dharmawibawa, I. D., dan Asy'ari, M. 2018. Pemberdayaan Kelompok Budidaya Jamur Tiram dalam Pemanfaatan Limbah Baglog Menjadi Pupuk Organik. Prosiding Seminar Nasional dan Diskusi Panel Multidisiplin Hasil Penelitian dan Pengabdian kepada Masyarakat, 727-733.

Izzati, M. F dan Wilopo. 2018. Implementasi Triple Helix dalam Mendorong Pertumbuhan Industri Kreatif di Kota Malang sebagai Upaya Peningkatan Daya Saing untuk Menghadapi Masyarakat Ekonomi ASEAN. Jurnal Administrasi Bisnis, 55(1), 59-68.

Murniati, D. E. 2009. Peran Perguruan Tinggi dalam Triple Helix sebagai Upaya Pengembangan Industri Kreatif. Prosiding Seminar Nasional PTBB 2009, 4 (1), 1-6. 
Nugroho, A. S., Rita, E., dan Ulfah, M. 2018. Manajemen Konservasi Anggrek Gunung Ungaran Berbasis Masyarakat sebagai Laboratorium Alam Pembelajaran Biologi. Laporan Penelitian Hibah PUPT No. 113. Semarang: Lembaga Penelitian dan Pengabdian kepada Masyarakat Universitas PGRI.

Palesangi, M. 2012. Pemuda Indonesia dan Kewirausahaan Sosial. Prosiding Seminar Nasional Competitive Advantage, 1-5. Universitas Pesantren Tinggi Darul Ulum.

Pranadji, T. 2006. Penguatan Modal Sosial untuk Pemberdayaan Masyarakat Pedesaan dalam Pengelolaan Agroekosistem Lahan Kering Studi Kasus Di Desa-desa (Hulu DAS) Ex Proyek Bangun Desa, Kabupaten Gunungkidul dan Ex Proyek Pertanian Lahan Kering, Kabupaten Boyolali. Jurnal Agro Ekonomi, 24(2), 178-206.

Praswati, A. N. 2017. Perkembangan Model Triple Helix dalam Peningkatan Inovasi. Prosiding Seminar Nasional Riset Manajemen dan Bisnis: Perkembangan Konsep dan Riset E-Business di Indonesia, 690-705.

Purnaningsih, N. 2007. Strategi Kemitraan Agribisnis Berkelanjutan. Sodality: Jurnal Sosiologi Pedesaan, 1(3), 393-416.
Rahman, A. Z. 2017. City Branding: Inovasi Peningkatan Daya Saing Daerah Masa Kini. In Fostering Innovation in Public Administration, 157-163.

Rochdiani, D., dan Suranta, K. J. 2007. Pola Kemitraan antara Petani Padi dengan PT. E-Farm Bisnis Indonesia dalam Meningkatkan Pendapatan Petani Padi. Sosiohumaniora, 9(1), 1-6.

Rombang, R. 1999. Gunung Ungaran. Jakarta: Bumi Aksara.

Sofia, I. P. 2015. Konstruksi Model Kewirausahaan Sosial (Social Entrepreneurship) sebagai Gagasan Inovasi Sosial bagi Pembangunan Perekonomian. Jurnal Universitas Pembangunan Jaya, 2(2), 2-23.

Utomo, H. 2014. Menumbuhkan Minat Kewirausahaan Sosial. Among Makarti, 7 (4), 1-16.

Yulianjaya, F., dan Hidayat, K. 2016. Pola Kemitraan Petani Cabai dengan Juragan Luar Desa (Studi Kasus Kemitraan Di Desa Kucur, Kecamatan Dau, Kabupaten Malang). Habitat, 27(1), 37-47. 